Supplement of Atmos. Chem. Phys., 21, 8127-8167, 2021

https://doi.org/10.5194/acp-21-8127-2021-supplement

(C) Author(s) 2021. CC BY 4.0 License.

(c) (1)

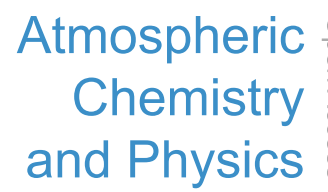

Supplement of

\title{
Improved representation of the global dust cycle using observational constraints on dust properties and abundance
}

\author{
Jasper F. Kok et al. \\ Correspondence to: Jasper F. Kok (jfkok@ucla.edu)
}

The copyright of individual parts of the supplement might differ from the article licence. 
This document contains a description of the atmospheric model simulations used in this study, namely CESM/CAM4, IMPACT, ModelE2, GEOS/GOCART, MONARCH, and INCA/IPSL. We also provide a description of how we account for correlation of errors in the constraint on the regional dust aerosol optical depth used in our inverse model. Finally, this document also contains a number of Supplementary Figures, which are summarized below:

- Figure S1. Spatial distribution of annually averaged bulk dust loading $\left(\mathrm{g} / \mathrm{m}^{2}\right)$ produced by a unit (1 $\mathrm{Tg}$ ) of total atmospheric dust loading produced by each of the nine source regions, as simulated by each of the six models in our model ensemble.

- Figure S2. Inverse model results for the seasonally resolved dust emission rate.

- Figure S3. Inverse model results for the seasonally resolved dust AOD.

- Figure S4. Inverse model results for the seasonally resolved dust column loading.

- Figure S5. Inverse model results for the seasonally resolved dust surface concentration.

- Figure S6. Inverse model results for the seasonally resolved dust deposition flux.

- Figure S7. Bulk global dust emission rate (a) and loading (b) as a function of the maximum simulated dust diameter.

- Figure S8. Comparison of model simulations against measurements of NH seasonal surface concentration.

- Figure S9. Comparison of model simulations against measurements of NH annual surface concentration.

- Figure S10. Comparison of model simulations against NH deposition flux measurements.

- Figure S11. Comparison of model simulations against measurements of SH seasonal surface concentration.

- Figure S12. Comparison of model simulations against measurements of SH annual surface concentration.

- Figure S13. Comparison of model simulations against SH deposition flux measurements.

\section{Description of CAM4 simulations}

We used the Community Atmosphere Model version 4 (CAM4) within the Community Earth System Model version 1.0.5 (CESM 1.0.5) to simulate the emission, transport and deposition of dust mineral aerosols (Hurrell et al., 2013) in order to calculate their radiative effects. Within CAM4, dust aerosols are treated as externally mixed and separated by particle size into four size bins $(0.1-1.0,1.0-2.5,2.5-5.0$, 5.0-10.0 $\mu \mathrm{m}$ ) using a bulk aerosol model (BAM) scheme. We extended the CAM4 simulation results by adding a 10-20 $\mu \mathrm{m}$ bin following the procedure in Adebiyi et al. (2020; see their section 2.3.1). Specifically, we calculated the $10-20 \mu \mathrm{m}$ bin in CAM4 as:

$$
\tilde{f}_{\mathrm{CAM} 4}\left(x, s,\left[D_{10}, D_{20}\right]\right)=\tilde{f}_{\mathrm{CAM} 4}\left(x, y, z,\left[D_{5}, D_{10}\right]\right) \cdot \frac{\tilde{f}_{\mathrm{GC}}\left(x, s,\left[D_{12}, D_{20}\right]\right)}{\tilde{f}_{\mathrm{GC}}\left(x, s,\left[D_{6}, D_{12}\right]\right)}
$$

where $\tilde{f}_{\mathrm{CAM} 4}$ and $\tilde{f}_{\mathrm{GC}}$ denote normalized (i.e., per $1 \mathrm{Tg}$ dust loading) dust fields (loading, concentration, and deposition) in respectively CAM4 and GOCART. As such, Eq. S1 uses the difference between the spatial distributions of the 12-20 and 6-12 $\mu \mathrm{m}$ particle bin dust fields in GOCART to approximate the difference between the spatial distributions of the 10-20 and 5-10 $\mu \mathrm{m}$ particle bin dust fields in CAM4.

Dust aerosol was subdivided into eight mineral species: calcite, feldspar, gypsum, hematite, illite, kaolinite, quartz, and smectite (Scanza et al., 2015; Scanza et al., 2018), with each mineral being advected 
as its own tracer in the model. The dust emission mineralogy was prescribed from offline soil mineralogy maps (Claquin et al., 1999). For this study, we also configured the Dust Entrainment and Deposition Model (DEAD) (Zender et al., 2003) to include the dust mobilization parameterization of Kok et al. (2014), which removes the offline soil erodibility map requirement and improves the model dust concentration and deposition comparisons with observations (Hamilton et al., 2019). Dust aerosol optical depth (AOD) was tuned to attain a global annual average of 0.03 , as suggested by Ridley et al. (2016). All simulations used a model resolution of $1.9^{\circ} \times 2.5^{\circ}$ (latitude by longitude) with 56 vertical levels from the surface to $2 \mathrm{hPa}$ and were run from 2003-2008. The last five years (2004-2008) were used for analysis. The model dynamics were forced offline by the European Centre for Medium-Range Weather Forecast's (ECMWF) global atmospheric reanalysis ERA-Interim meteorology (Dee et al., 2011).

\section{Description of IMPACT simulations}

This study used the Integrated Massively Parallel Atmospheric Chemical Transport (IMPACT) model to calculate the concentration of mineral dust aerosols in 4 size bins (diameters: $0.1-1.26,1.26-2.5,2.5-5$, and 5-20 $\mu \mathrm{m}$ ) (Ito et al., 2020 and references therein). The model was driven by the Modern Era Retrospective analysis for Research and Applications 2 (MERRA-2) reanalysis meteorological data from the NASA Global Modeling and Assimilation Office (GMAO) (Gelaro et al., 2017) with a horizontal resolution of $2.0^{\circ}$ latitude by $2.5^{\circ}$ longitude and 59 vertical layers for the years of 2004 and 2005 . The global scaling factor of dust emissions in 2005 was scaled down by 0.8685 from that in 2004 , which resulted in global dust emissions ranging from $4875 \mathrm{Tg} /$ year in 2005 to $6773 \mathrm{Tg} /$ year in 2004. The IMPACT model simulated the emissions, vertical diffusion, advection, gravitational settling, convection, dry deposition, wet scavenging and photochemistry of major aerosol species, which include mineral dust, Fe-containing combustion aerosols, black carbon, organic carbon, sea spray aerosols, sulfate, nitrate, ammonium, and secondary organic aerosols, and their precursor gases. We calculated dust emissions using a physically-based emission scheme in conjunction with satellite products of vegetation cover and soil moisture in the model (Kok et al., 2014; Ito and Kok, 2017). The satellite-based estimates of fractional vegetation area in conjunction with land cover type were used to account for suppressing effects of vegetation on dust emission in barren and open shrublands (Webb et al., 2014; Ito and Kok, 2017). The chemical composition of mineral dust aerosols can change dynamically from that in the originally emitted aerosols due to reactions with gaseous species. The aging of mineral dust aerosols from hydrophobic to hydrophilic can enhance their gravitational settling, dry and wet deposition (Wang and Penner, 2009; Ito et al., 2020). Atmospheric concentrations and depositions of aerosols have been evaluated extensively on global and regional scales (Myriokefalitakis et al., 2018; Ito et al., 2019). To

100 isolate the contribution of each of the specified source regions to the global dust loading, we tagged the dust originating from each source region.

\section{Description of ModelE2.1 simulations}

The NASA Goddard Institute for Space Studies (GISS) ModelE2.1 calculates the emission, transport and removal of dust aerosols in five size bins, whose diameters span $0.1-2 \mu \mathrm{m}, 2-4 \mu \mathrm{m}, 4-8 \mu \mathrm{m}, 8-16 \mu \mathrm{m}$ and 16-32 $\mu \mathrm{m}$, respectively. The smallest bin corresponds to clay sized particles, while the remainder represent silt sizes. We did not use the largest bin $(16-32 \mu \mathrm{m})$ because it exceeds the $20 \mu \mathrm{m}$ maximum diameter used in the inverse model and instead generated a $16-20 \mu \mathrm{m}$ bin based on the $8-16 \mu \mathrm{m}$ bin and the GOCART 12-20 $\mu \mathrm{m}$ bin, as follows (also see description of the CAM4 simulations and Adebiyi et al., 2020):

$$
\tilde{f}_{\mathrm{E} 2.1}\left(x, s,\left[D_{16}, D_{20}\right]\right)=\tilde{f}_{\mathrm{E} 2.1}\left(x, y, z,\left[D_{8}, D_{16}\right]\right) \cdot \frac{\tilde{f}_{\mathrm{GC}}\left(x, s,\left[D_{12}, D_{20}\right]\right)}{\tilde{f}_{\mathrm{GC}}\left(x, s,\left[D_{6}, D_{12}\right]\right)} .
$$


ModelE2.1 has horizontal resolution of $2^{\circ}$ latitude by $2.5^{\circ}$ longitude and 40 vertical layers that extend to $0.1 \mathrm{hPa}$ just above the stratopause (Bauer et al., 2020; Kelley et al., 2020).

Dust emission occurs where loosely bound soil particles are abundant and vulnerable to wind erosion in the absence of vegetation. Regions of dust emission are prescribed using the source map of Ginoux et al. (2001) that combines a satellite vegetation mask with a geomorphological criterion identifying sources as basins where soils are replenished by erosion from surrounding highlands. This map results in a distribution of dust sources that corresponds to well-known dust "hot spots": localized regions where aerosol optical depth is frequently high (Prospero et al., 2002). Soil particles are emitted when the wind speed exceeds a prescribed threshold that increases with soil moisture. The model also represents

120 emission by wind gusts that are ephemeral compared to the duration over which surface wind speed is updated by the model (Cakmur et al., 2004). The cubic dependence of emission upon wind speed is based upon wind tunnel measurements (Shao et al., 1993). The mass of emitted dust for a given wind speed is calibrated using a worldwide collection of measurements (Cakmur et al., 2006). In particular, the emitted ratio of clay and silt particles is prescribed to match retrievals of the aerosol size distribution at several

125 AERONET stations in regions of high dust concentration. This results in a ratio consistent with measurements of the emitted size distribution compiled by Kok (2011).

Dust aerosols are transported by the model winds, which in this study are relaxed to four-times daily NCEP values (Kalnay et al., 1996). The relaxation time at all model levels is $1000 \mathrm{~s}$ (just under 20 minutes), a duration chosen to match the observed circulation including vertical motion. The NCEP 130 winds are linearly interpolated in time between their successive 6-hour values.

Dust is removed from the atmosphere through turbulent removal near the surface and gravitational settling (Wesely and Hicks, 1977; Koch et al., 1999). In addition, removal occurs within clouds when particles nucleate cloud droplets and ice crystals. Dust is also removed both within and below clouds when particles are captured through collisions with precipitation. Falling droplets that completely

135 reevaporate during descent release the dust particle (Bauer and Koch, 2005; Schmidt et al., 2006).

More information about the calculation of the dust life cycle is given by Miller et al. (2006) and Perlwitz et al. (2015). The dust distribution has been compared to an extensive collection of measurements, for example by Cakmur et al. (2006), Miller et al. (2006), and Huneeus et al. (2011).

\section{Description of GEOS/GOCART simulations}

140 This study used the NASA Goddard Earth Observing System (GEOS) global Earth systems model, which incorporates coupled components for atmospheric and oceanic circulation and atmospheric chemistry and composition, and state-of-the-art data assimilation capabilities for both atmospheric dynamics and aerosols (Rienecker et al., 2008). Aerosol processes are represented using a version of the Goddard Chemistry Aerosol Radiation and Transport (GOCART) (Chin et al., 2002; Colarco et al., 2010).

145 GOCART is run online within GEOS in a configuration that replays meteorology from a previous atmospheric analysis, in this case from the Modern-Era Retrospective analysis for Research and Applications, version 2 (MERRA-2) (Gelaro et al., 2017; Randles et al., 2017). In this study, simulations were run on a cubed-sphere horizontal grid at $\sim 100 \mathrm{~km}$ resolution with 72 vertical hybrid-sigma levels extending from the surface to $1 \mathrm{~Pa}$ (around $80 \mathrm{~km}$ ). GOCART models the emissions, mixing, chemistry, 150 and deposition of major aerosol components in the troposphere, including sulfates, nitrates, dust, black carbon, organic carbon, and sea-salt aerosols. Dust emissions were calculated using an updated version of the scheme described in Ginoux et al. (2001). Dust is described with 8 size bins spaced between $0.1-10$ $\mu \mathrm{m}$ radius. The four submicron particles size bins (radius $<1 \mu \mathrm{m}$ ) are grouped in one unique bin for 
emission and transport purposes. The initial dust particle size distribution was tuned to follow the brittle fragmentation theory approach of Kok (2011). Dust optical properties are modeled using spheroidal shape assumptions, after Colarco et al. (2014).

\section{Description of MONARCH simulations}

The Multiscale Online Non-hydrostatic AtmospheRe CHemistry model (MONARCH; previously known as NMMB/BSC-CTM) is a model developed at the Barcelona Supercomputing Center (e.g., Pérez et al., 2011; Badía et al., 2017). MONARCH contains advanced chemistry and aerosol packages, and it is coupled online with the Non-hydrostatic Multiscale Model (NMMB), which allows for running either global or high-resolution (convection-permitting) regional simulations (Janjic et al., 2001; Janjic and Gall, 2012).

The dust module of MONARCH (Pérez et al., 2011; Haustein et al., 2012) solves the mass balance equation for dust taking into account the following processes: (1) dust generation and uplift by surface wind and turbulence, (2) horizontal and vertical advection, (3) horizontal diffusion and vertical transport by turbulence and convection, (4) dry deposition and gravitational settling and (5) wet removal including incloud and below-cloud scavenging from convective and stratiform clouds. Several different parameterizations of dust emission are available in $\mathrm{MONARCH}$, namely those from Marticorena and Bergametti (1995), Ginoux et al. (2001) with modifications detailed below, Shao (2001, 2004), Shao et al. (2011), Kok et al. (2014), and Klose et al. (2014). Potential dust source areas can be described using either the topographic dust source function from Ginoux et al. (2001) or the frequency of occurrence of Moderate Resolution Imaging Spectroradiometer (MODIS) Deep Blue dust optical depth exceeding 0.2 (Hsu et al., 2004; Ginoux et al., 2012). Areas fully covered by vegetation, water, snow, or bedrock are excluded from potential dust sources. The drag partition corrections to account for roughness elements at the ground surface can be chosen to follow either Marticorena and Bergametti (1995) with a correction published by King et al. (2005), or Raupach et al. (1993). The model simulations performed for this study utilize the dust emission scheme from Ginoux et al. (2001) with some modifications described in the following. The dust emission flux for particle size bin $k, F_{k}$, is computed as

$$
F_{k}=S f_{k} u_{*}^{2}\left(u_{*}-u_{* t}\right) \quad \text { if } u *>u_{*}
$$

180 with friction velocity $u *$ and threshold friction velocity $u_{*}$. The fraction of particles in size bin $d$ is given by $f_{k}$ and follows Kok (2011). $S$ is the topographic source function described by Ginoux et al. (2001). The threshold friction velocity for a smooth and dry surface, $u_{*}$, , is calculated as the minimum value obtained using the formulation from Shao and $\mathrm{Lu}(2000)$. Threshold friction velocity, $u_{*}$, is then obtained by applying corrections for the effects of soil moisture $\left(f_{w}\right)$ and vegetation cover $\left(f_{v}\right)$ as

$$
u_{* t}=u_{* t 0} \cdot f_{w} \cdot f_{v}
$$

The correction factor for soil moisture, $f_{w}$, follows Ginoux et al. (2001). $f_{v}$ is based on Raupach et al. (1993) and requires frontal area index $\lambda$ as an input, which we estimate based on monthly satellite-based retrievals of photosynthetic and non-photosynthetic vegetation cover (Guerschman et al., 2015) using the logarithmic relationship (Shao et al., 1996)

$$
\lambda=-c_{\lambda} \ln (1-\eta)
$$

with fractional vegetation cover $\eta$ and $c_{\lambda}=0.35$. The photosynthetic vegetation fraction is also used in the land-surface modules, which warrants consistency within MONARCH. Potential dust source areas are specified using the frequency of occurrence of MODIS Deep Blue dust optical depth larger than 0.2 (Ginoux et al., 2012). 
The model includes eight dust size transport bins ranging up to $20 \mu \mathrm{m}$ in diameter. The effective and volume radii of the bins used in the radiative and sedimentation schemes respectively are time-invariant and based on a lognormal distribution with mass median diameter of $2.524 \mu \mathrm{m}$ and geometric standard deviation of 2 .

The model runs performed with MONARCH are conducted at a horizontal resolution of $1.0^{\circ}$ latitude by $1.4^{\circ}$ longitude with 48 vertical layers and a computational time step of $3 \mathrm{~min}$. Turbulence, surface layer, dust emission, sedimentation and dry deposition routines are called every 4 computational times steps (12 $\mathrm{min}$ ), moist convection, microphysics and wet scavenging routines every 8 time steps (24 min), and shortand longwave radiation routines are called every 20 time steps $(60 \mathrm{~min})$. MONARCH runs are initialized using ERA Interim reanalysis data (Dee et al., 2011). The meteorological fields are re-initialized daily, while dust fields and soil moisture are transferred between the daily runs. We used one year of spinup for soil moisture and one month of spinup for the dust fields before the 5-year simulation time period 2004 2008. To isolate the contribution of each of the specified source regions to the global dust loading, we tagged the dust originating from each source region.

\section{Description of INCA simulations}

210 For this study the online coupled climate model IPSL-CM6 (Boucher et al., submitted) is used with the LMDzORINCAv6 configuration, which includes interactive aerosols and simplified chemistry. Well mixed trace gases concentrations/emissions are forced with AMIP/CMIP6 datasets (Lurton et al., submitted), solar forcing following Matthes et al. (2017), and the ozone concentrations used are described in Checa-Garcia et al. (2018). The coupled model uses the dynamical core of LMDZ [(Hourdin et al.,

215 2013) with nudged monthly wind-fields from ERA-Interim (Dee et al., 2011), forced by sea-surface temperatures and sea-ice concentrations and coupled to a land surface model (ORCHIDEE) (Krinner et al., 2005) and the aerosol and chemistry model INCA (INteraction with Chemisty and Aerosols) (Hauglustaine et al., 2004). The model covers both the troposphere and stratosphere with 79 hybrid-sigma layers, and with a spatial resolution of $2.5 \times 1.25$ degrees. A cross-comparisons between nudged and non-

220 nudged simulations shows 15\% larger emissions in the latter case, for aerosols that are emitted by interactive surface-winds with a single coarse dust mode.

The aerosol size-distribution is represented by a multi-modal scheme which describes each aerosol species with one or more log-normal modes (Balkanski et al., 2004; Schulz et al., 2009). The INCA version used here implements black-carbon, nitrate, sulfate, ammonium, and organic aerosols with a combination of accumulation and coarse log-normal modes (both soluble and insoluble). In contrast, seasalt is described by three soluble modes (accumulation, coarse and super-coarse). We use prescribed dimethyl sulfide (DMS), and secondary organic aerosols are not accounted for. Mineral dust is described by a new scheme (Di Biagio et al., 2020) based on 4 insoluble modes with following mass median diameters (MMD) at emission of 1.0, 2.5, 7.0 and $22.0 \mu \mathrm{m}$, and sigmas of 1.8, 2.0, 1.9, and 2.0

230 respectively. The prescribed size distribution at emission is partitioned among the four modes $(0.57 \%$, $4.2 \%, 30.8 \%, 62.4 \%$ ), which ensures consistency with Kok et al. (2017) and measurements from the Fennec field campaign Experiment Ryder et al. (2013).

The different dust diagnostics $X(\theta, \phi, p, t ; M)$ estimated by INCA are given for each mode $M$. For the inter-model comparison based on size intervals, a post-processing of these diagnostics remap the results into a bins/sectional scheme, $X(\theta, \phi, p, t ; M)$ with upper bin limits at 2, 3.6, 6, 12, 20,30,40,100 $\mu \mathrm{m}$, using a monthly time resolution. Of these bins, only the bins with upper limit up to $20 \mu \mathrm{m}$ are used in this study. The size distribution at emission has prescribed invariant mass median diameters MMD, therefore the binning process, $\mathrm{X}(\mathrm{M})->\mathrm{X}(\mathrm{B})$, is accurate for emitted fluxes. The concentrations are distributed 
amongst the binned intervals based on $\operatorname{MMD}(\theta, \phi, p, t ; M)$ fields for the 4 modes, and the loadings have been estimated using these binned concentrations. Wet and dry deposition fluxes were binned starting from the modal diagnostics using the MMD associated to the surface layer. This approximates the exact deposition fluxes which depend on the vertical size distribution which varies temporally and spatially. Therefore, in order to force mass conservation for each dust size bin, globally and seasonally-averaged correction factors $c(B)$ were applied to both wet and dry deposition for each bin, such that $X^{\prime}(B)=$ $c(B) X(B)$, and were $X^{\prime}$ is the effective wet or dry deposition flux. We used as constraint for these correction factors that deposited mass per bin, integrated over the globe and the season, equals the total emitted mass per bin, also integrated over the globe and the season. These correction factors ranged between 0.5 and 1.5, and as such are relatively small compared to average error between model results and measurements of deposition fluxes (Figs. 7c, 10c). The methodology and code used to transform the modal description into the bin description is described in Checa-Garcia (2020).

\section{Treatment of error correlation in the DAOD constraints}

As described in the main text, we assume that the magnitude of errors that are completely random between seasons and regions $\left(\bar{\sigma}_{s, \text { rand }}^{p}\right)$, systematic errors that are correlated between different seasons for the same region $\left(\bar{\sigma}_{\text {seas }}^{p}\right)$, and systematic errors that are correlated across regions for a given season $\left(\bar{\sigma}_{s, \text { reg }}\right)$ are all equal. That is, we assume that

$$
\bar{\sigma}_{s, \text { rand }}^{p}=\bar{\sigma}_{s, \text { reg }}^{2}=\bar{\sigma}_{\text {seas }}^{p}=\frac{1}{3} \bar{\sigma}_{s}^{p^{2}}
$$

Specifically, we obtain a realization of the seasonally-averaged DAOD for a given source region as follows

$$
\bar{\tau}_{s}^{p}=\bar{\tau}_{s, \text { mean }}^{p}+N\left(0, \bar{\sigma}_{s, \text { rand }}^{p} ; x=x_{p, s}\right)+N\left(0, \bar{\sigma}_{\text {seas }}^{p} ; x=x_{p}\right)+N\left(0, \bar{\sigma}_{s, \text { reg }} ; x=x_{s}\right),
$$

where $\bar{\tau}_{s, \text { mean }}^{p}$ denotes the mean DAOD for region $p$ and season $s$ (see Table 2). Further, $N(0, \sigma ; x)$ denotes a normal distribution with mean of 0 and standard deviation $\sigma$, which is sampled at its cumulative distribution at the point $x$, which denotes a randomly-drawn number between 0 and 1 . The random number $x_{p, s}$ quantifies the point on the normal distribution of the random error and thus has different values for different seasons $s$ and different DAOD-constrained regions $p$; the random number $x_{p}$ denotes the systematic error that stays constant for different seasons at a given region, and is thus equal for the different seasons but varies for different DAOD-constrained regions $p$; finally, the random number $x_{s}$ denotes the systematic error that stays constant for different regions for a given season, and is thus equal for the different DAOD-constrained regions $p$ but varies for different seasons $s$. 


\section{Supplementary Figures}
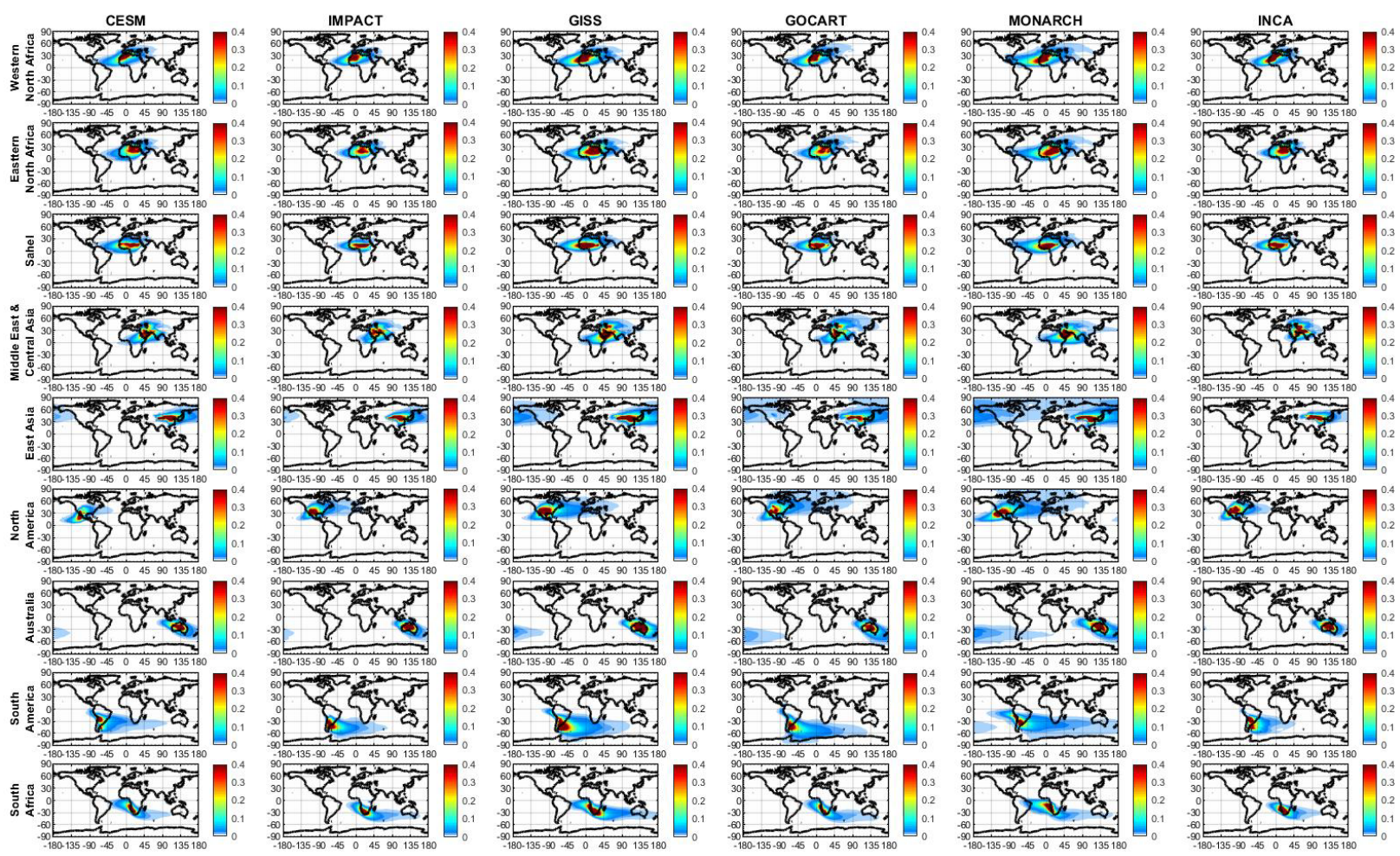

270 Figure S1. Spatial distribution of annually-averaged bulk dust loading $\left(\mathrm{g} / \mathrm{m}^{2}\right)$ produced by a unit $(1 \mathrm{Tg})$ of total atmospheric dust loading produced by each of the nine source regions, as simulated by each of the six models in our model ensemble.
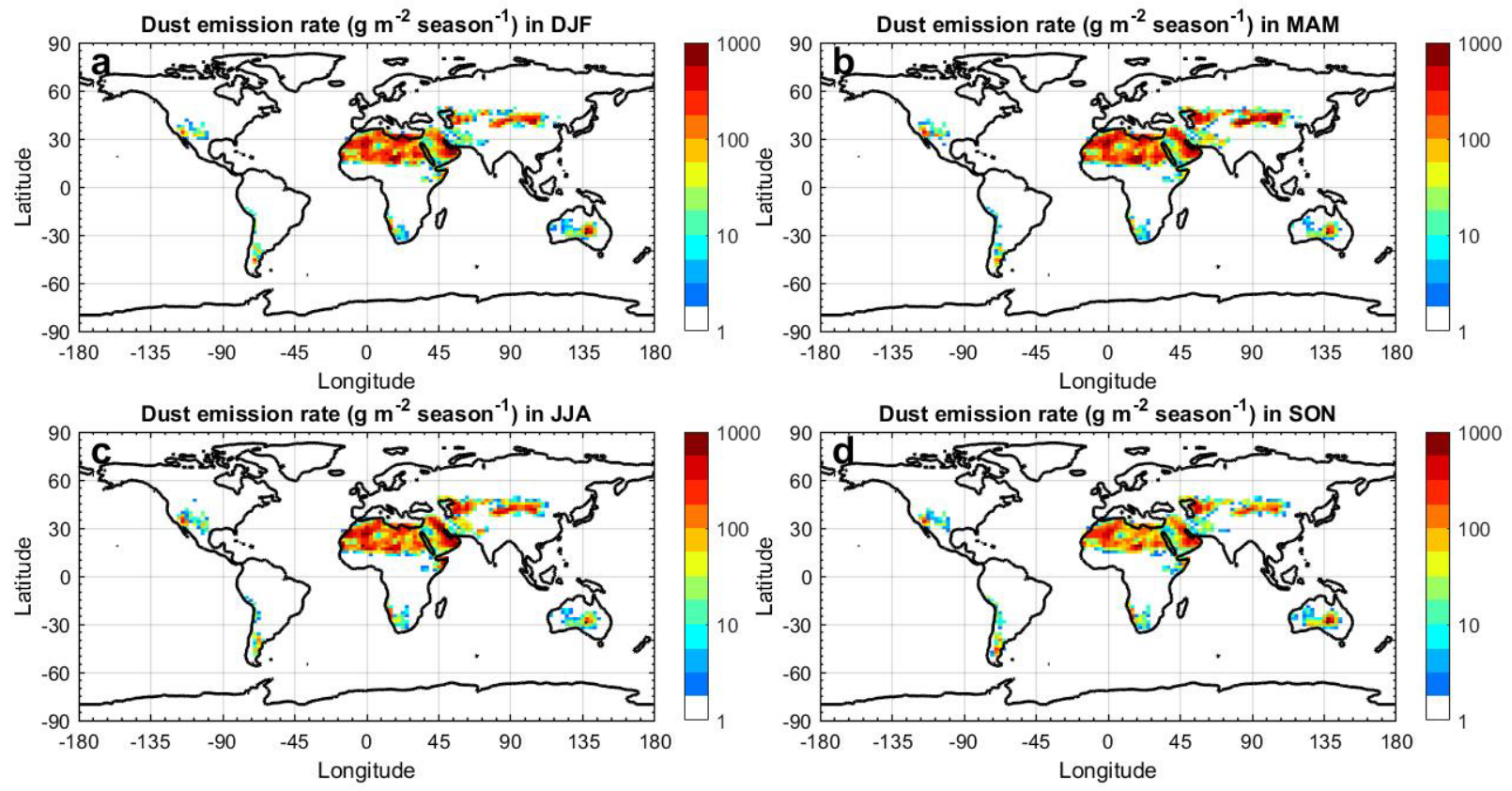

Figure S2. Inverse model results for the seasonally resolved $\mathrm{PM}_{20}$ dust emission flux. 

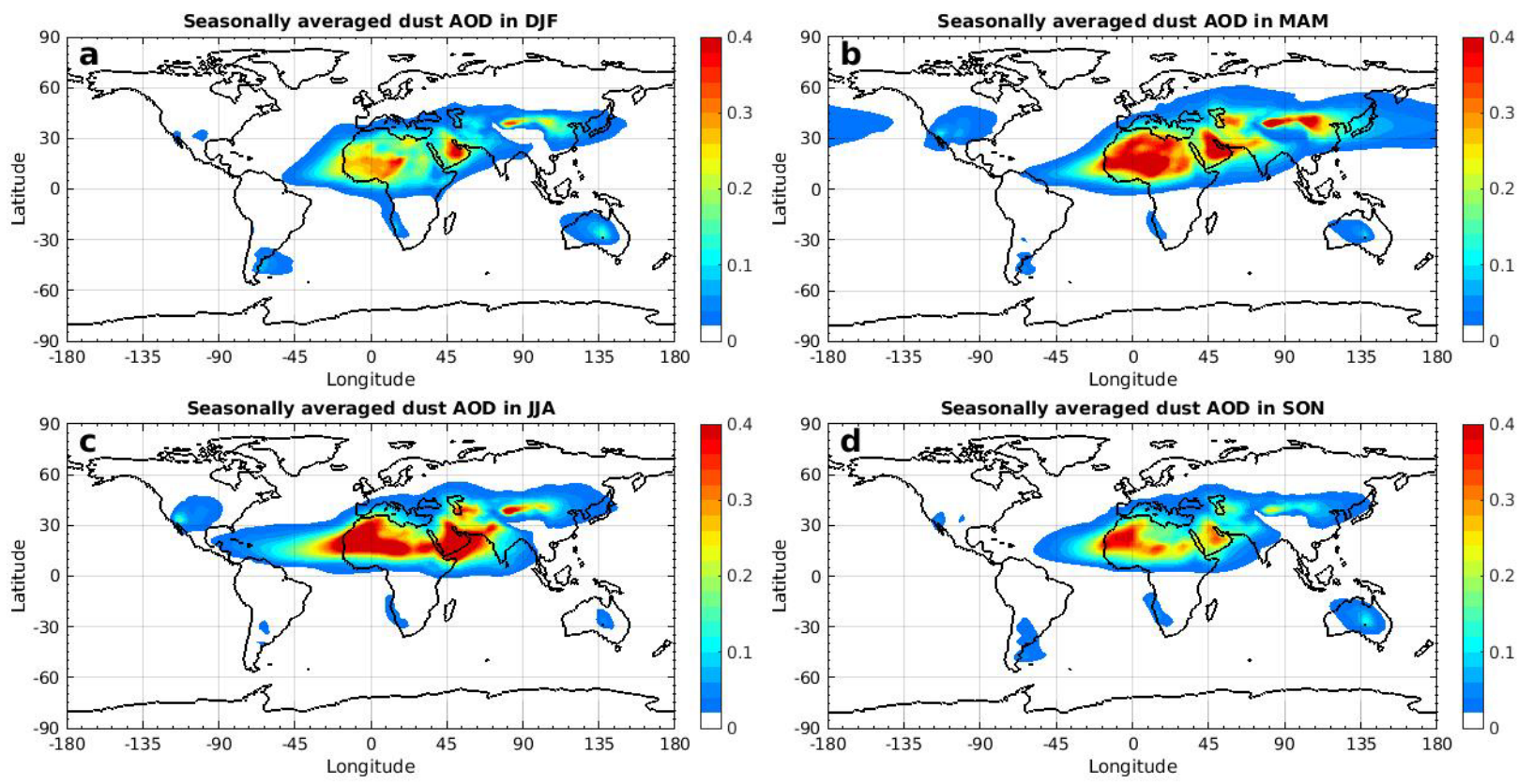

Figure S3. Inverse model results for the seasonally resolved $\mathrm{PM}_{20}$ dust AOD.
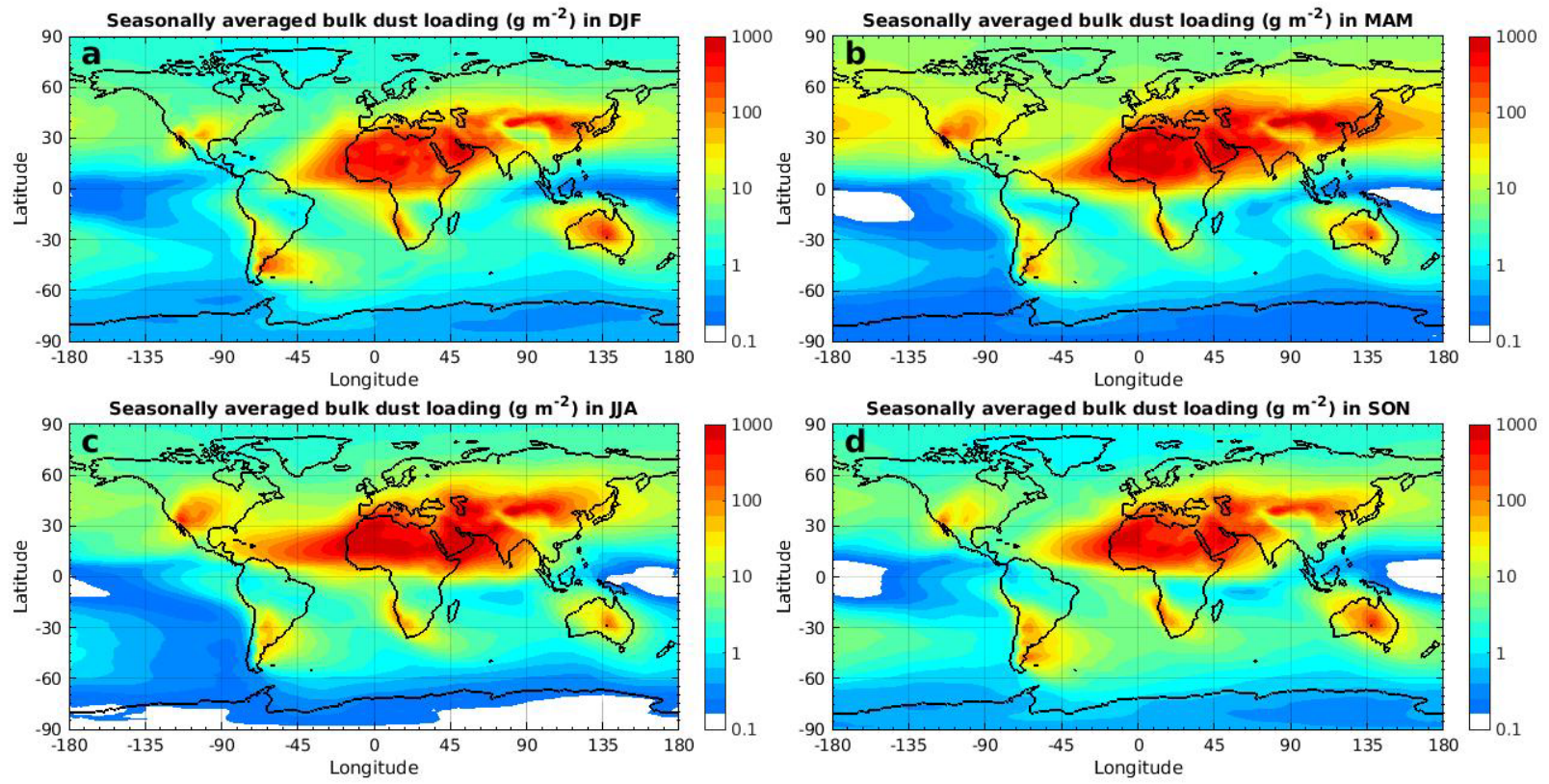

Figure S4. Inverse model results for the seasonally resolved $\mathrm{PM}_{20}$ dust column loading. 

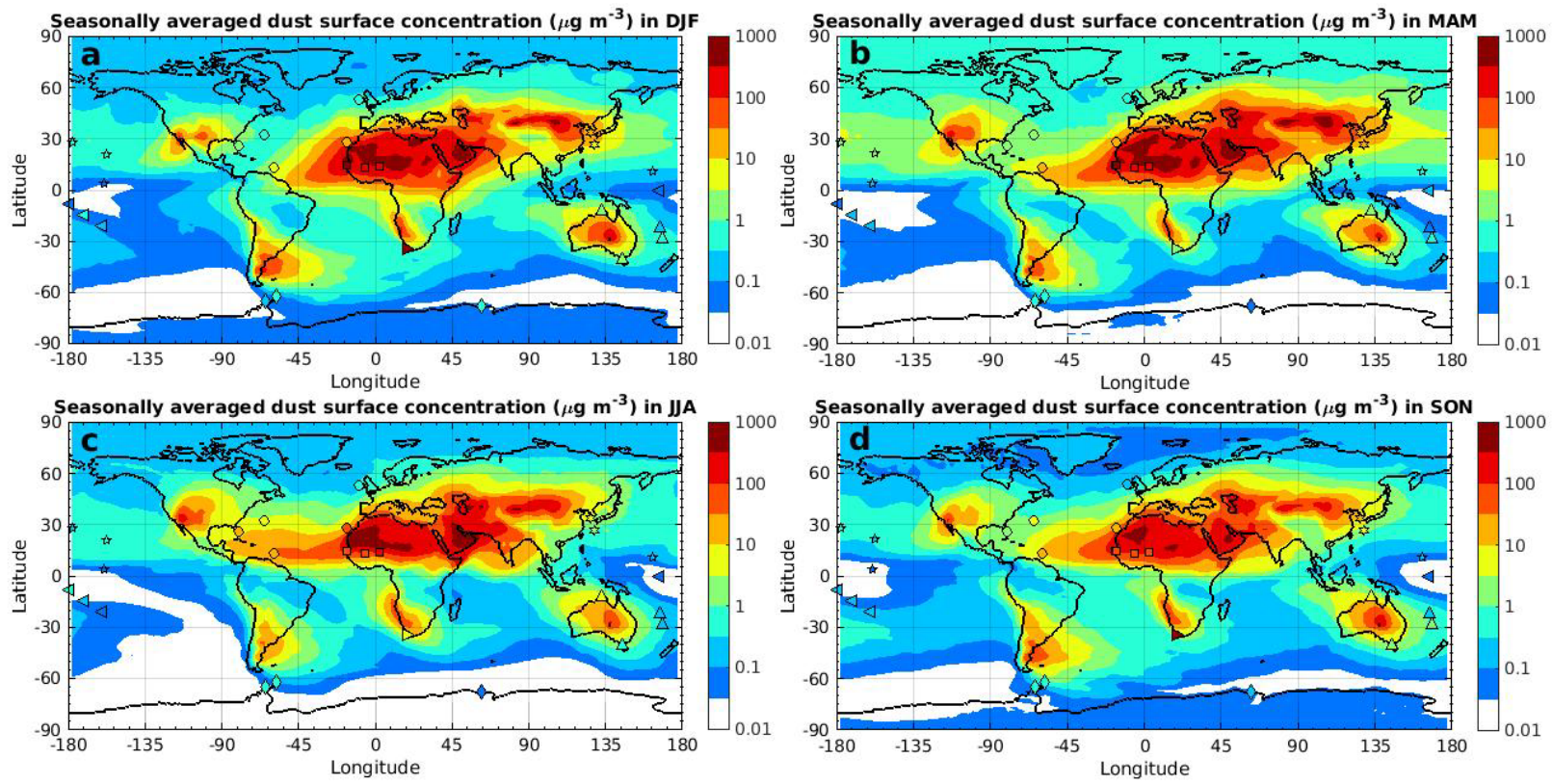

Figure S5. Inverse model results for the seasonally resolved $\mathrm{PM}_{20}$ dust surface concentration.
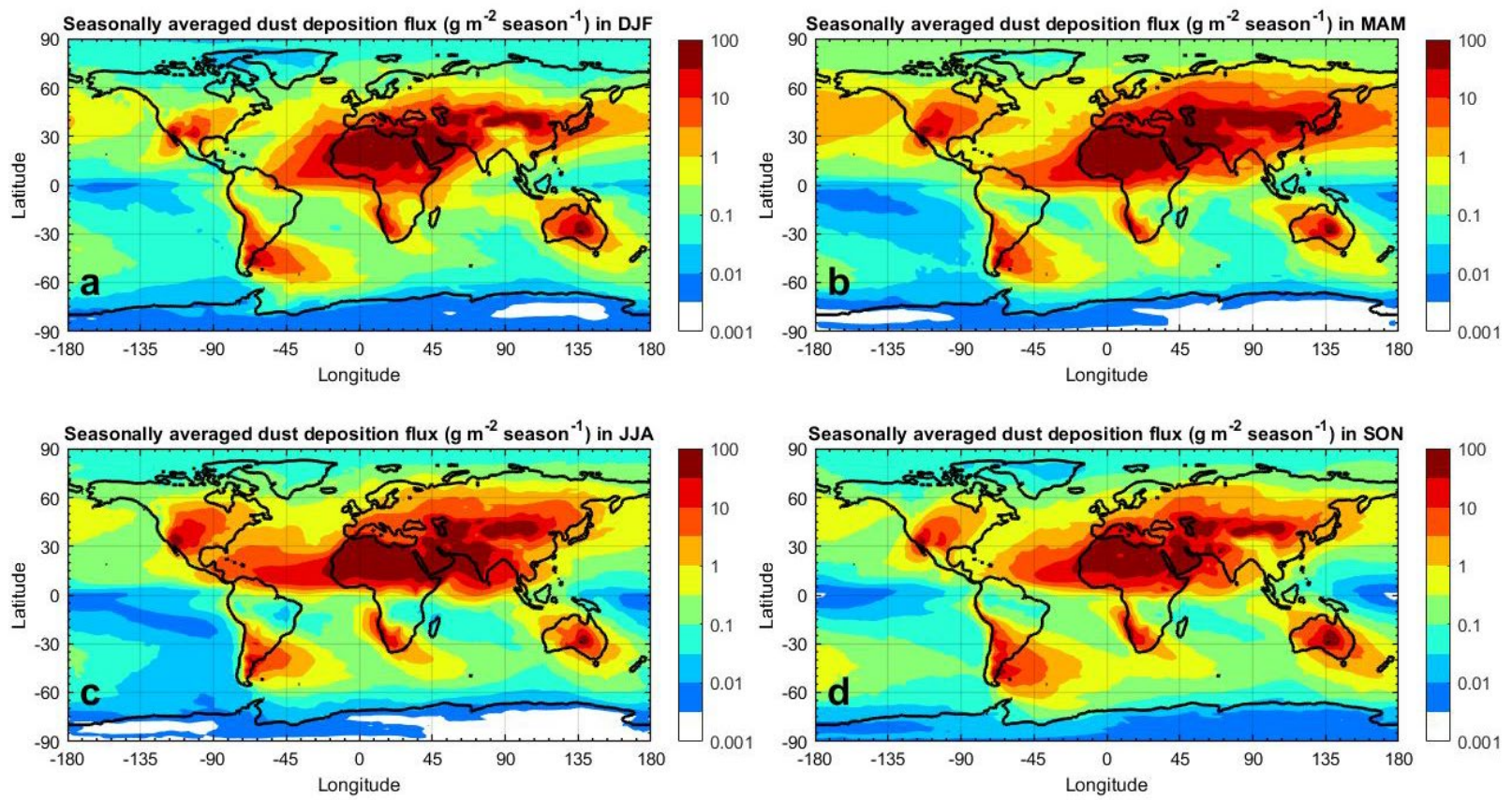

Figure S6. Inverse model results for the seasonally resolved $\mathrm{PM}_{20}$ dust deposition flux. 

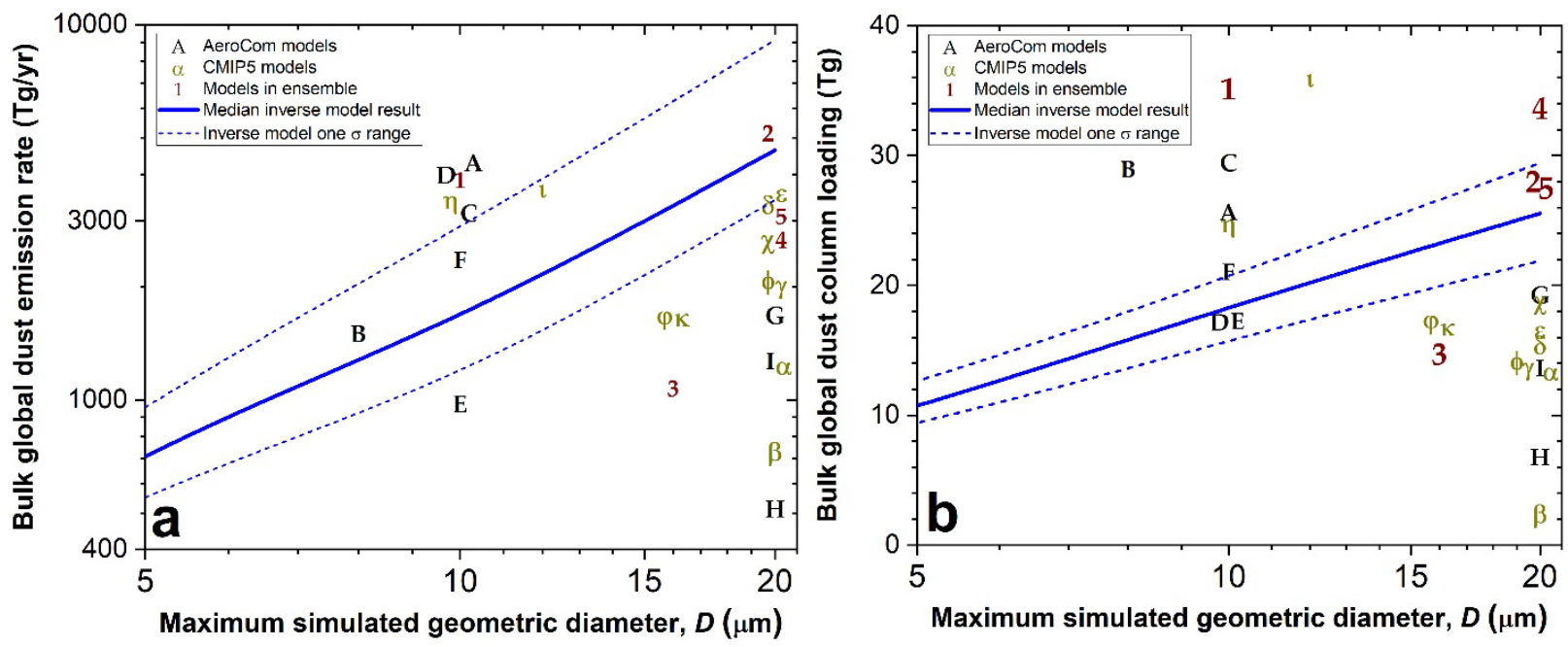

Figure S7. Bulk global dust emission rate (a) and loading (b) as a function of the maximum simulated dust diameter. Shown are results from the AeroCom model ensemble (from Huneeus et al., 2011; black letters; exact legend in Fig. 3), the CMIP5 model ensemble (from Wu et al., 2020; dark yellow Greek letters; $\alpha=$ GFDL-CM3, $\beta=$ MIROC $4 \mathrm{~h}, \psi=$ MIROC5,$\delta=$ MIROC-ESM, $\varepsilon=$ MIROC-ESM-CHEM, $\phi=$ MRI-CGCM3, $\gamma=$ MRI-ESM1, $\eta=$ CESM1-CAM5, $\imath=$ CSIRO-Mk3-6-0, $\varphi=$ GISS-E2-H, $\kappa=$ GISS-E2-R), our model ensemble (brown letters; exact legend in Fig. 3). For all three ensembles, only sectional models with a maximum diameter less than $20 \mu \mathrm{m}$ are shown and some models are slightly offset horizontally to avoid overlap. Median results (blue solid line) and one standard error range (blue dashed lines) of the inverse model were obtained by integrating global dust emission fluxes and atmospheric loading up until the indicated maximum geometric diameter.

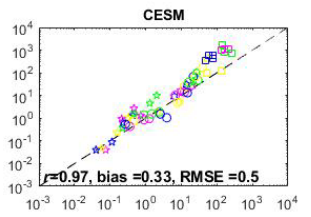

INCA

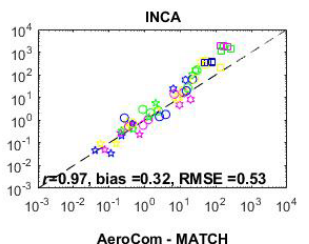

AeroCom - MATCH

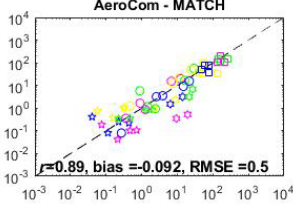

AeroCom-LSCE

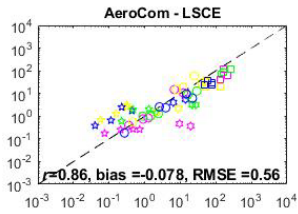

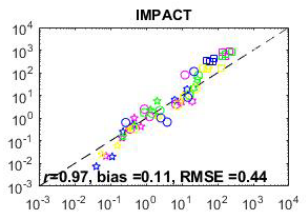

AeroCom - CAM

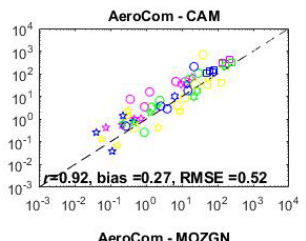

AeroCom - MOZGN

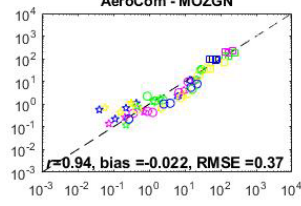

AeroCom - ECHAM5

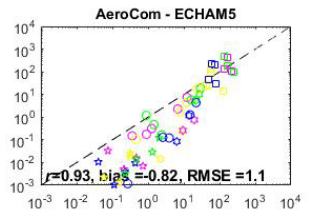

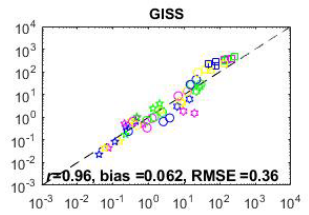

AeroCom-GIss

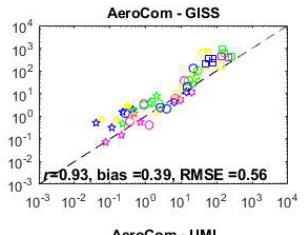

AeroCom - UM!



AeroCom - MIRAGE

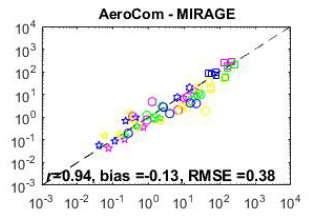

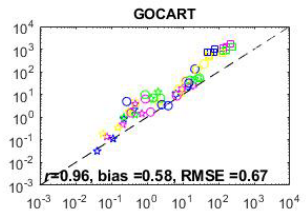

AeroCom - GoCART

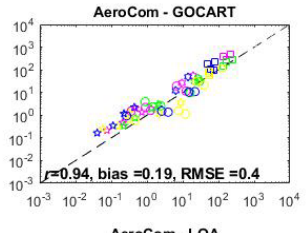

AeroCom - LOA

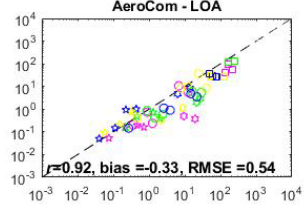

AeroCom - TM5

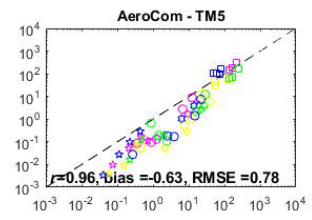

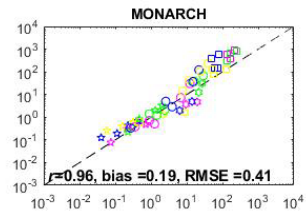

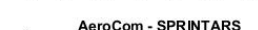

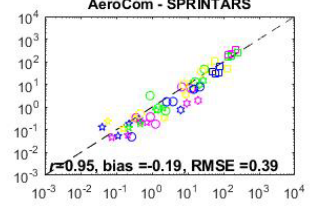

AeroCom - UIO-CтM

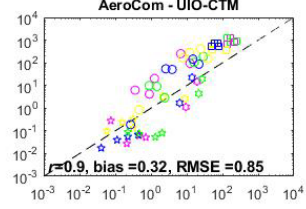

MERRA2

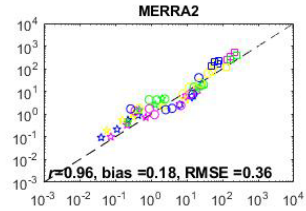

Figure S8. Comparison of measurements of the seasonally averaged dust surface concentration $\left(\mu \mathrm{g} \mathrm{m}^{-3}\right)$ in the Northern Hemisphere with predictions from individual models. Included are results from the six models in the model ensemble as well as the 13 AeroCom phase 1 models. Symbol types denote different regions as defined in Fig. $6 \mathrm{a}$, and different colors refer to different seasons (magenta $=\mathrm{DJF}$, green $=$ MAM, yellow $=\mathrm{JJA}$, and blue $=$ SON). 


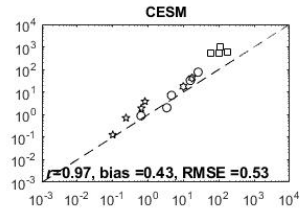

INCA

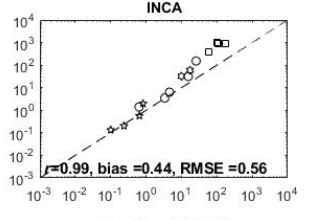

AeroCom - MATCH

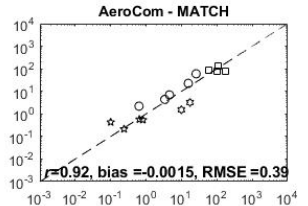

AeroCom - LSCE

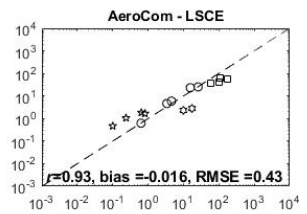

IMPACT

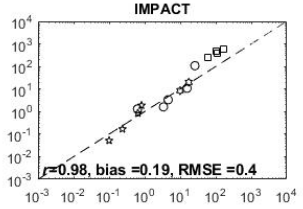

AeroCom - CAM



AeroCom - MOZGN

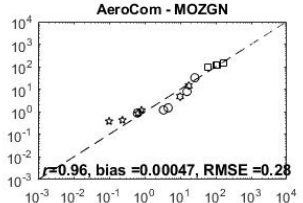

AeroCom - ECHAM5

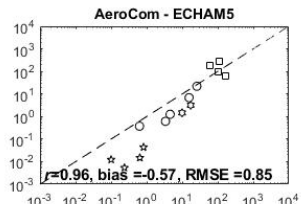

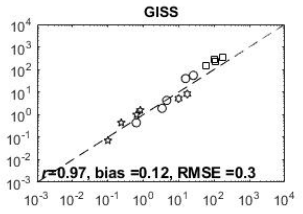

AeroCom-GISS

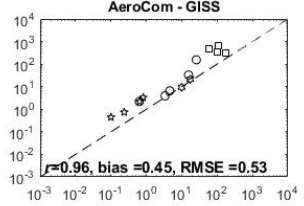

AeroCom - UMI

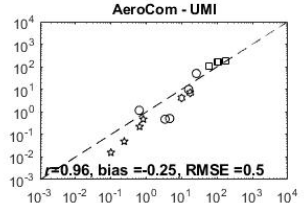

AeroCom - MIRAGE

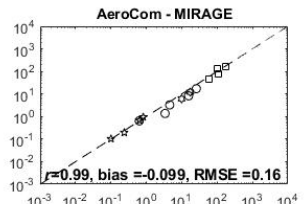

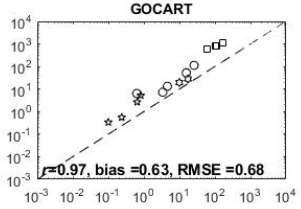

AeroCom - GOCART

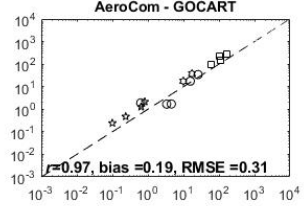

AeroCom -LOA

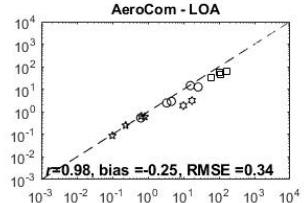

AeroCom - TM5

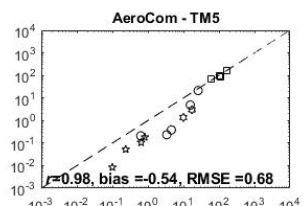

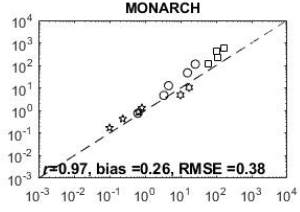



AeroCom-UIO-CTM

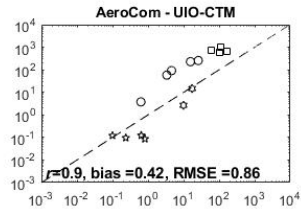

MERRA2

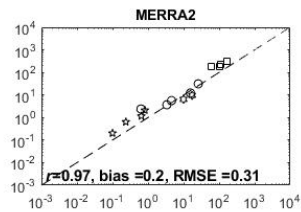

Figure S9. Comparison of measurements of the annually averaged dust surface concentration $\left(\mu \mathrm{g} \mathrm{m}^{-3}\right)$ in the Northern Hemisphere with predictions from individual models. Included are results from the six models in the model ensemble as well as the 13 AeroCom phase 1 models. Symbol types denote different regions as defined in Fig. 6 b.

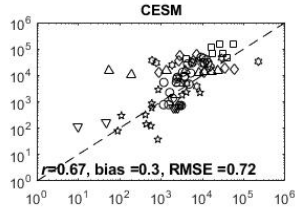

INCA
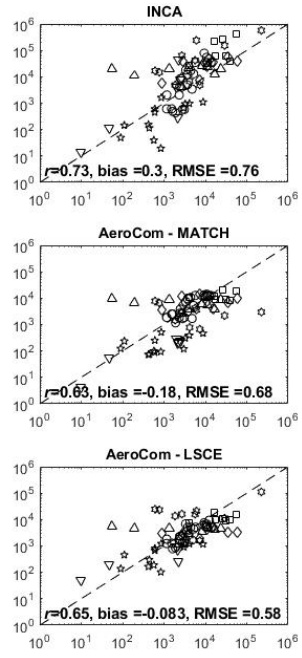
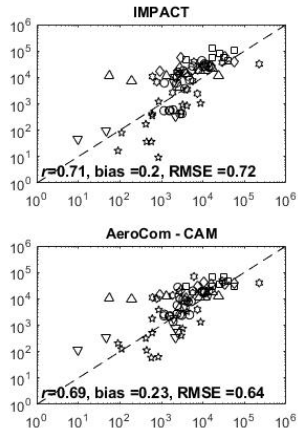

AeroCom - MOZGN
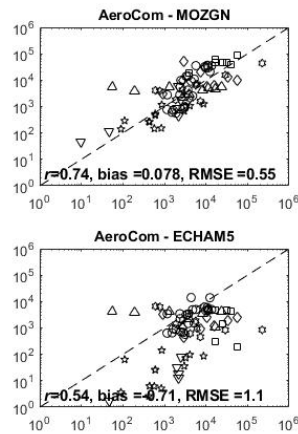

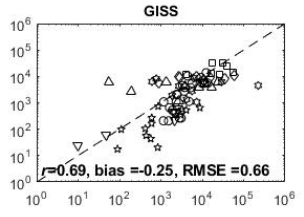

AeroCom-GISS

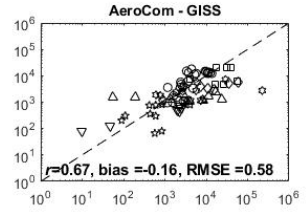

AeroCom - UMI
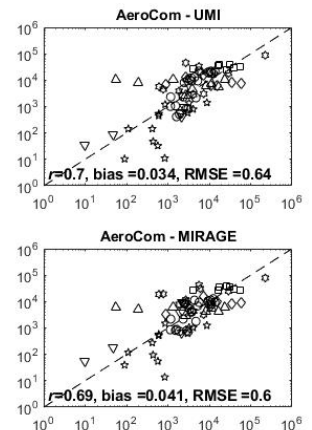
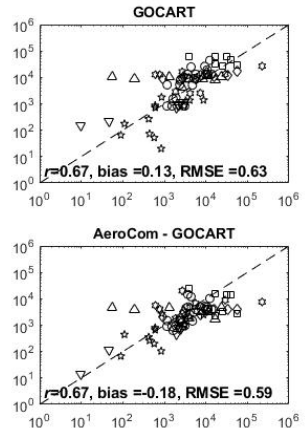

AeroCom - LOA

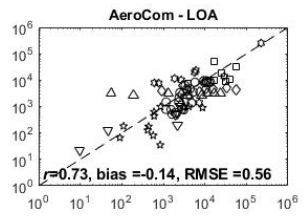

AeroCom - TM5

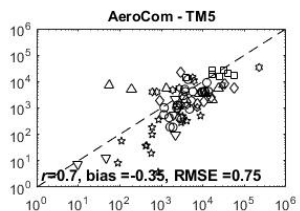

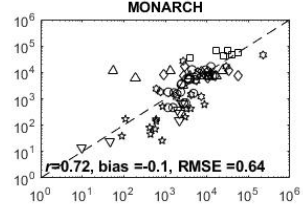
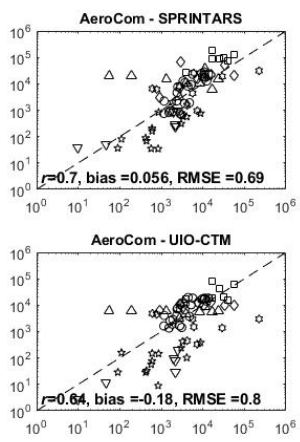

MERRA2

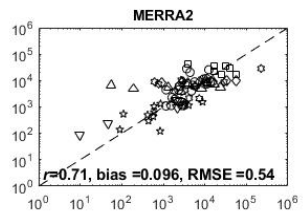

Figure S10. Comparison of measurements of the annually averaged dust deposition flux $\left(\mathrm{mg} \mathrm{m}^{-2} \mathrm{yr}^{-1}\right)$ in the Northern Hemisphere with predictions from individual models. Included are results from the six models in the model ensemble as well as the 13 AeroCom phase 1 models. Symbol types denote different regions as defined in Fig. 6c. 

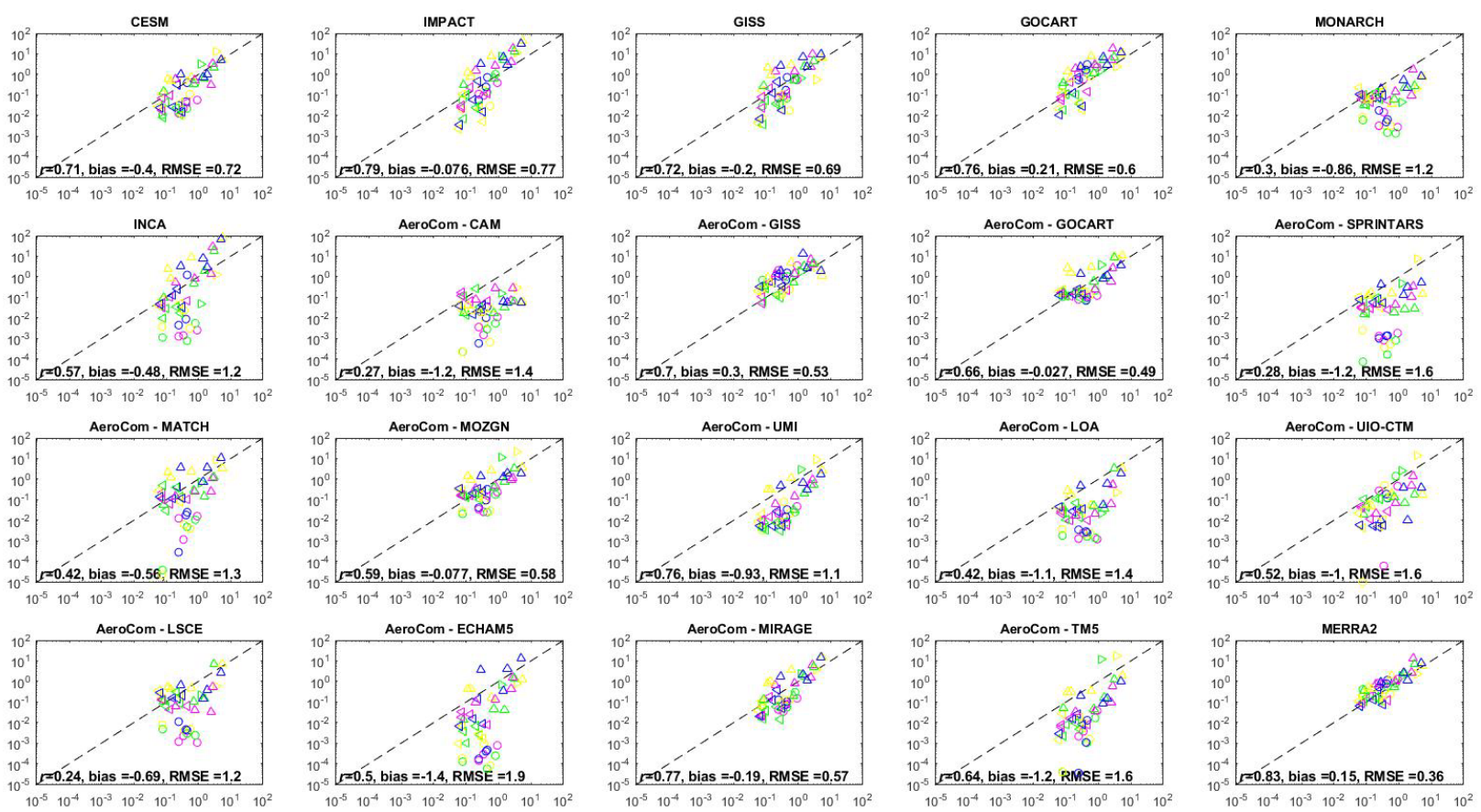

Figure S11. Comparison of measurements of the seasonally averaged dust surface concentration $\left(\mu \mathrm{g} \mathrm{m}^{-3}\right)$ in the Southern Hemisphere with predictions from individual models. Included are results from the six models in the model ensemble as well as the 13 AeroCom phase 1 models. Symbol types denote different regions as defined in Fig. 9a, and different colors refer to different seasons (magenta $=$ DJF, green $=$ MAM, yellow $=J J A$, and blue $=$ SON).
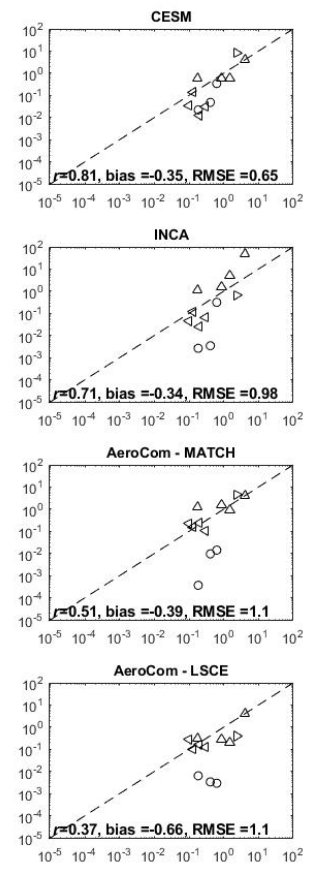

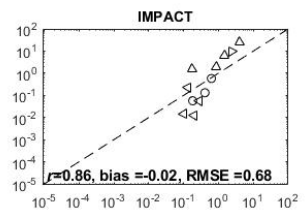

AeroCom - CAM
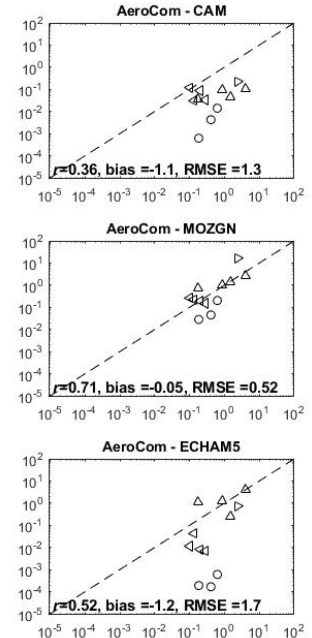



AeroCom-GISs

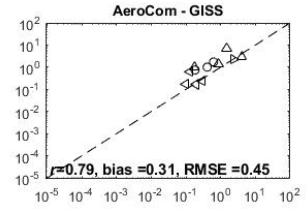

AeroCom - UMI

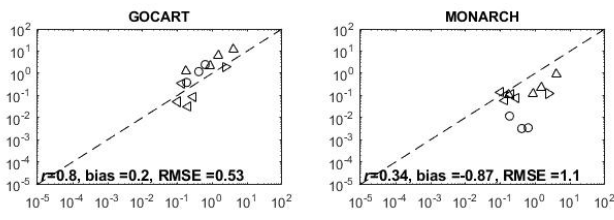

AeroCom - GOCART
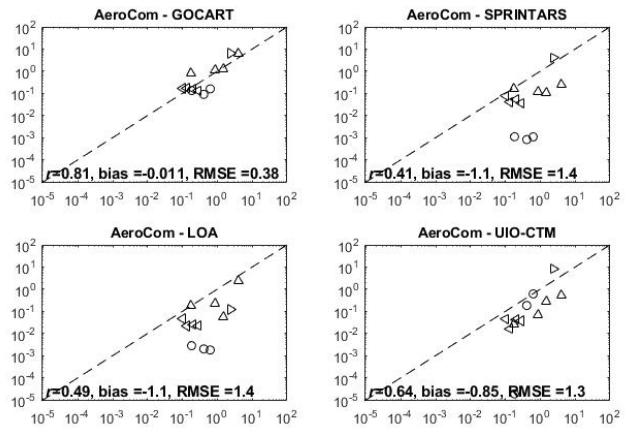

AeroCom - TM5

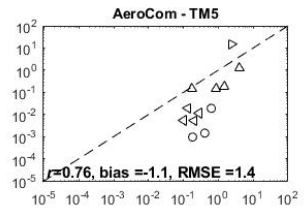

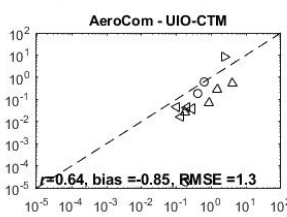

MERRA2

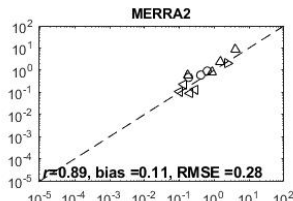

Figure S12. Comparison of measurements of the annually averaged dust surface concentration $\left(\mu \mathrm{g} \mathrm{m}^{-3}\right)$ in the Southern Hemisphere with predictions from individual models. Included are results from the six models in the model ensemble as well as the 13 AeroCom phase 1 models. Symbol types denote different regions as defined in Fig. 9a. 

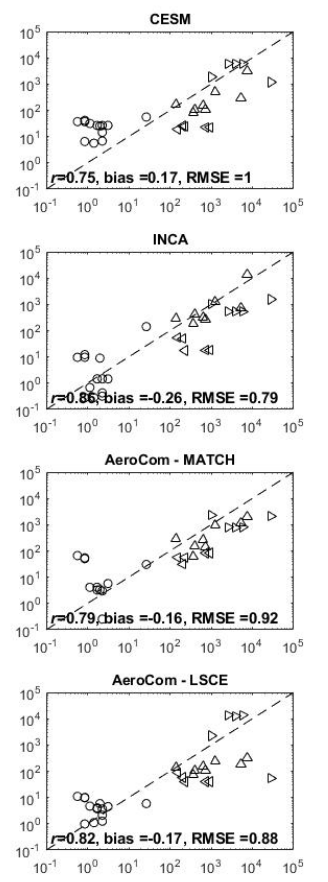
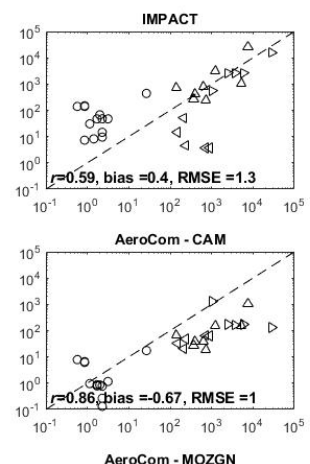

AeroCom - MOZGN

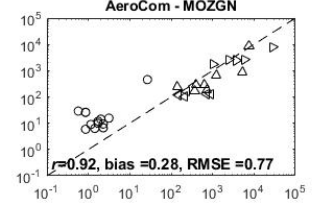

AeroCom - ECHAM5

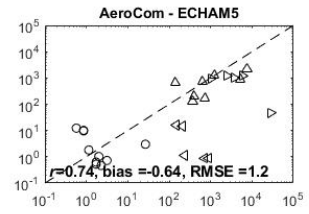

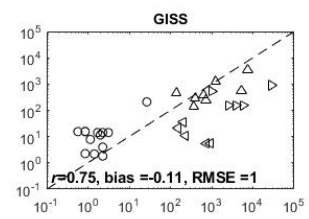

AeroCom - GISs

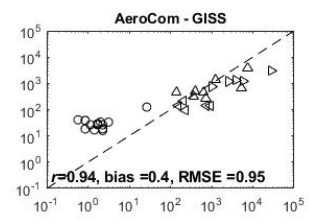

AeroCom - UMI

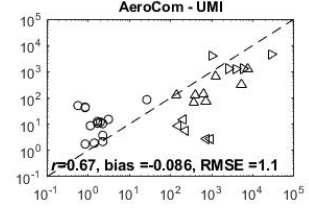

AeroCom - MIRAGE

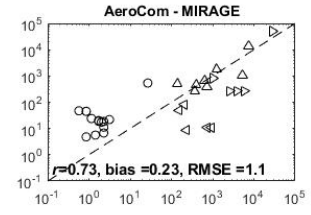

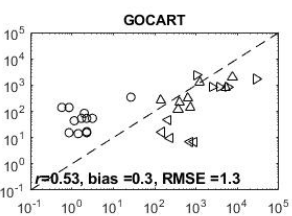

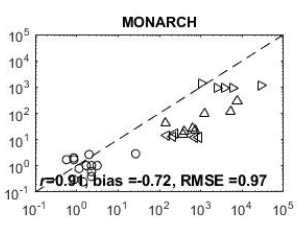

AeroCom - GOCART

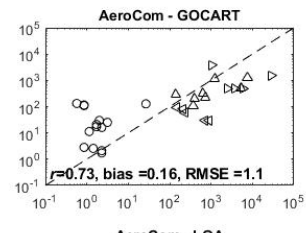

AeroCom - LOA

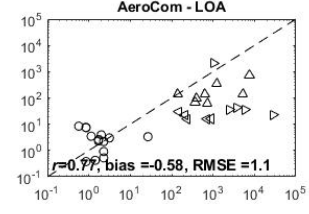

AeroCom - TM5

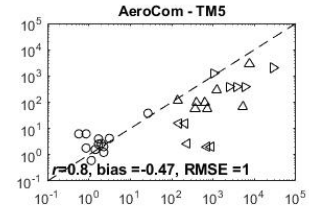

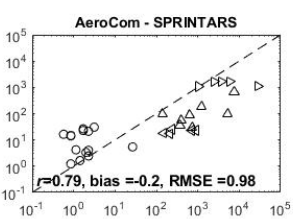

AeroCom - UIO-СтM



MERRA2

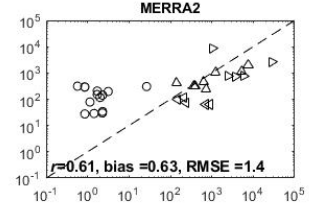

Figure S13. Comparison of measurements of the annually averaged dust deposition flux $\left(\mathrm{mg} \mathrm{m}^{-2} \mathrm{yr}^{-1}\right)$ in the

Southern Hemisphere with predictions from individual models. Included are results from the six models in the model ensemble as well as the 13 AeroCom phase 1 models. Symbol types denote different regions as defined in Fig. 9c.

\section{References}

Adebiyi, A. A., Kok, J. F., Wang, Y., Ito, A., Ridley, D. A., Nabat, P., and Zhao, C.: Dust Constraints from joint Observational-Modelling-experiMental analysis (DustCOMM): comparison with measurements and model simulations, Atmospheric Chemistry and Physics, 20, 829-863, 2020.

Badia, A., Jorba, O., Voulgarakis, A., Dabdub, D., Garcia-Pando, C. P., Hilboll, A., Goncalves, M., and Janjic, Z.: Description and evaluation of the Multiscale Online Nonhydrostatic AtmospheRe CHemistry model (NMMB-MONARCH) version 1.0: gas-phase chemistry at global scale, Geoscientific Model Development, 10, 609-638, 2017.

Balkanski, Y., Schulz, M., Moulin, C., and Ginoux, P.: The formulation of dust emissions on global scale: formulation and validation using satellite retrievals. In: Emissions of Atmospheric Trace Compounds, Granier, C., Artaxo, P., and Reeves, C. (Eds.), Kluwer Academic Publishers, Dordrecht, 2004.

Bauer, S. E. and Koch, D.: Impact of heterogeneous sulfate formation at mineral dust surfaces on aerosol loads and radiative forcing in the Goddard Institute for Space Studies general circulation model, Journal of Geophysical Research-Atmospheres, 110, 2005.

Bauer, S. E., Tsigaridis, K., Faluvegi, G., Kelley, M., Lo, K. K., Miller, R. L., Nazarenko, L., Schmidt, G. A., and Wu, J. B.: Historical (1850-2014) Aerosol Evolution and Role on Climate Forcing Using the GISS ModelE2.1 Contribution to CMIP6, J. Adv. Model. Earth Syst., 12, 2020.

Cakmur, R. V., Miller, R. L., Perlwitz, J., Geogdzhayev, I. V., Ginoux, P., Koch, D., Kohfeld, K. E., Tegen, I., and Zender, C. S.: Constraining the magnitude of the global dust cycle by minimizing the difference between a model and observations, Journal of Geophysical Research-Atmospheres, 111, D06207, 2006. 
Cakmur, R. V., Miller, R. L., and Torres, O.: Incorporating the effect of small-scale circulations upon dust emission in an atmospheric general circulation model, Journal of Geophysical ResearchAtmospheres, 109, 2004.

Checa-Garcia, R.: FunFAN: FUNctions For Aerosol Modelling. Zenodo, 2020.

Checa-Garcia, R., Hegglin, M. I., Kinnison, D., Plummer, D. A., and Shine, K. P.: Historical Tropospheric and Stratospheric Ozone Radiative Forcing Using the CMIP6 Database, Geophysical Research Letters, 45, 3264-3273, 2018.

Chin, M., Ginoux, P., Kinne, S., Torres, O., Holben, B. N., Duncan, B. N., Martin, R. V., Logan, J. A., Higurashi, A., and Nakajima, T.: Tropospheric aerosol optical thickness from the GOCART model and comparisons with satellite and Sun photometer measurements, J. Atmos. Sci., 59, 461-483, 2002.

Claquin, T., Schulz, M., and Balkanski, Y. J.: Modeling the mineralogy of atmospheric dust sources, Journal of Geophysical Research-Atmospheres, 104, 22243-22256, 1999.

Colarco, P., da Silva, A., Chin, M., and Diehl, T.: Online simulations of global aerosol distributions in the NASA GEOS-4 model and comparisons to satellite and ground-based aerosol optical depth, Journal of Geophysical Research-Atmospheres, 115, 2010.

365 Colarco, P. R., Nowottnick, E. P., Randles, C. A., Yi, B. Q., Yang, P., Kim, K. M., Smith, J. A., and Bardeen, C. G.: Impact of radiatively interactive dust aerosols in the NASA GEOS-5 climate model: Sensitivity to dust particle shape and refractive index, Journal of Geophysical Research-Atmospheres, 119, 753-786, 2014.

Dee, D. P., Uppala, S. M., Simmons, A. J., Berrisford, P., Poli, P., Kobayashi, S., Andrae, U., Balmaseda, M. A., Balsamo, G., Bauer, P., Bechtold, P., Beljaars, A. C. M., van de Berg, L., Bidlot, J., Bormann, N., Delsol, C., Dragani, R., Fuentes, M., Geer, A. J., Haimberger, L., Healy, S. B., Hersbach, H., Holm, E. V., Isaksen, L., Kallberg, P., Kohler, M., Matricardi, M., McNally, A. P., Monge-Sanz, B. M., Morcrette, J. J., Park, B. K., Peubey, C., de Rosnay, P., Tavolato, C., Thepaut, J. N., and Vitart, F.: The ERA-Interim reanalysis: configuration and performance of the data assimilation system, 375 Quarterly Journal of the Royal Meteorological Society, 137, 553-597, 2011.

Di Biagio, C., Balkanski, Y., Albani, S., Boucher, O., and Formenti, P.: Direct Radiative Effect by Mineral Dust Aerosols Constrained by New Microphysical and Spectral Optical Data, Geophysical Research Letters, 47, 2020.

Gelaro, R., McCarty, W., Suarez, M. J., Todling, R., Molod, A., Takacs, L., Randles, C. A., Darmenov, A., Bosilovich, M. G., Reichle, R., Wargan, K., Coy, L., Cullather, R., Draper, C., Akella, S., Buchard, V., Conaty, A., da Silva, A. M., Gu, W., Kim, G. K., Koster, R., Lucchesi, R., Merkova, D., Nielsen, J. E., Partyka, G., Pawson, S., Putman, W., Rienecker, M., Schubert, S. D., Sienkiewicz, M., and Zhao, B.: The Modern-Era Retrospective Analysis for Research and Applications, Version 2 (MERRA-2), Journal of Climate, 30, 5419-5454, 2017.

385 Ginoux, P., Chin, M., Tegen, I., Prospero, J. M., Holben, B., Dubovik, O., and Lin, S. J.: Sources and distributions of dust aerosols simulated with the GOCART model, J. Geophys. Res., 106, 2025520273, 2001.

Ginoux, P., Prospero, J. M., Gill, T. E., Hsu, N. C., and Zhao, M.: Global-scale attribution of anthropogenic and natural dust sources and their emission rates based on MODIS Deep Blue aerosol products, Reviews of Geophysics, 50, Rg3005, 2012.

Guerschman, J. P., Scarth, P. F., McVicar, T. R., Renzullo, L. J., Malthus, T. J., Stewart, J. B., Rickards, J. E., and Trevithick, R.: Assessing the effects of site heterogeneity and soil properties when unmixing photosynthetic vegetation, non-photosynthetic vegetation and bare soil fractions from Landsat and MODIS data, Remote Sensing of Environment, 161, 12-26, 2015.

395 Hamilton, D. S., Scanza, R. A., Feng, Y., Guinness, J., Kok, J. F., Li, L. L., Liu, X. H., Rathod, S. D., Wan, J. S., Wu, M. X., and Mahowald, N. M.: Improved methodologies for Earth system modelling of atmospheric soluble iron and observation comparisons using the Mechanism of Intermediate complexity for Modelling Iron (MIMI v1.0), Geoscientific Model Development, 12, 3835-3862, 2019. 
Hauglustaine, D. A., Hourdin, F., Jourdain, L., Filiberti, M. A., Walters, S., Lamarque, J. F., and Holland, E. A.: Interactive chemistry in the Laboratoire de Meteorologie Dynamique general circulation model: Description and background tropospheric chemistry evaluation, Journal of Geophysical Research-Atmospheres, 109, 2004.

Haustein, K., Perez, C., Baldasano, J. M., Jorba, O., Basart, S., Miller, R. L., Janjic, Z., Black, T., Nickovic, S., Todd, M. C., Washington, R., Muller, D., Tesche, M., Weinzierl, B., Esselborn, M., and Schladitz, A.: Atmospheric dust modeling from meso to global scales with the online NMMB/BSCDust model - Part 2: Experimental campaigns in Northern Africa, Atmospheric Chemistry and Physics, 12, 2933-2958, 2012.

Hourdin, F., Grandpeix, J. Y., Rio, C., Bony, S., Jam, A., Cheruy, F., Rochetin, N., Fairhead, L., Idelkadi, A., Musat, I., Dufresne, J. L., Lahellec, A., Lefebvre, M. P., and Roehrig, R.: LMDZ5B: the atmospheric component of the IPSL climate model with revisited parameterizations for clouds and convection, Clim. Dyn., 40, 2193-2222, 2013.

Hsu, N. C., Tsay, S. C., King, M. D., and Herman, J. R.: Aerosol properties over bright-reflecting source regions, IEEE Trans. Geosci. Remote Sens., 42, 557-569, 2004.

Huneeus, N., Schulz, M., Balkanski, Y., Griesfeller, J., Prospero, J., Kinne, S., Bauer, S., Boucher, O., Chin, M., Dentener, F., Diehl, T., Easter, R., Fillmore, D., Ghan, S., Ginoux, P., Grini, A., Horowitz, L., Koch, D., Krol, M. C., Landing, W., Liu, X., Mahowald, N., Miller, R., Morcrette, J. J., Myhre, G., Penner, J., Perlwitz, J., Stier, P., Takemura, T., and Zender, C. S.: Global dust model intercomparison in AeroCom phase I, Atmos. Chem. Phys., 11, 7781-7816, 2011.

Hurrell, J. W., Holland, M. M., Gent, P. R., Ghan, S., Kay, J. E., Kushner, P. J., Lamarque, J. F., Large, W. G., Lawrence, D., Lindsay, K., Lipscomb, W. H., Long, M. C., Mahowald, N., Marsh, D. R., Neale, R. B., Rasch, P., Vavrus, S., Vertenstein, M., Bader, D., Collins, W. D., Hack, J. J., Kiehl, J., and Marshall, S.: The Community Earth System Model A Framework for Collaborative Research, Bulletin of the American Meteorological Society, 94, 1339-1360, 2013.

Ito, A. and Kok, J. F.: Do dust emissions from sparsely vegetated regions dominate atmospheric iron supply to the Southern Ocean?, Journal of Geophysical Research-Atmospheres, 122, 3987-4002, 2017.

Ito, A., Myriokefalitakis, S., Kanakidou, M., Mahowald, N. M., Scanza, R. A., Hamilton, D. S., Baker, A. R., Jickells, T., Sarin, M., Bikkina, S., Gao, Y., Shelley, R. U., Buck, C. S., Landing, W. M., Bowie, A. R., Perron, M. M. G., Guieu, C., Meskhidze, N., Johnson, M. S., Feng, Y., Kok, J. F., Nenes, A., and Duce, R. A.: Pyrogenic iron: The missing link to high iron solubility in aerosols, Science Advances, 5, 2019.

Ito, A., Ye, Y., Yamamoto, A., Watanabe, M., and Aita, M. N.: Responses of ocean biogeochemistry to atmospheric supply of lithogenic and pyrogenic iron-containing aerosols, Geological Magazine, 157, 741-756, 2020.

Janjic, Z. and Gall, R.: Scientific documentation of the NCEP Nonhydrostatic Multiscale Model on the B grid (NMMB), National Center for Atmospheric Research, Camp Springs, MD, USA., 2012.

Janjic, Z. I., Gerrity, J. P., and Nickovic, S.: An alternative approach to nonhydrostatic modeling, Monthly Weather Review, 129, 1164-1178, 2001.

Kalnay, E., Kanamitsu, M., Kistler, R., Collins, W., Deaven, D., Gandin, L., Iredell, M., Saha, S., White, G., Woollen, J., Zhu, Y., Chelliah, M., Ebisuzaki, W., Higgins, W., Janowiak, J., Mo, K. C., Ropelewski, C., Wang, J., Leetmaa, A., Reynolds, R., Jenne, R., and Joseph, D.: The NCEP/NCAR 40-year reanalysis project, Bulletin of the American Meteorological Society, 77, 437-471, 1996.

Kelley, M., G.A. Schmidt, L. Nazarenko, R.L. Miller, S.E. Bauer, R. Ruedy, G.L. Russell, I. Aleinov, M. Bauer, R. Bleck, V. Canuto, G. Cesana, Y. Cheng, T.L. Clune, B. Cook, C.A. Cruz, A.D. Del Genio, G.S. Elsaesser, G. Faluvegi, N.Y. Kiang, D. Kim, A.A. Lacis, A. Leboissetier, A.N. LeGrande, K.K. Lo, J.C. Marshall, S. McDermid, E.E. Matthews, K. Mezuman, L.T. Murray, V. Oinas, C. Orbe, C. Pérez García-Pando, J.P. Perlwitz, M.J. Puma, D. Rind, A. Romanou, D.T. Shindell, S. Sun, N. Tausnev, K. Tsigaridis, G. Tselioudis, E. Weng, J. Wu, and Yao, M.: GISS-E2.1: Configurations and climatology, J. Adv. Model. Earth Syst., 12, e2019MS002025, 2020. 
King, J., Nickling, W. G., and Gillies, J. A.: Representation of vegetation and other nonerodible elements in aeolian shear stress partitioning models for predicting transport threshold, Journal of Geophysical Research-Earth Surface, 110, 2005.

Klose, M., Shao, Y. P., Li, X. L., Zhang, H. S., Ishizuka, M., Mikami, M., and Leys, J. F.: Further development of a parameterization for convective turbulent dust emission and evaluation based on field observations, Journal of Geophysical Research-Atmospheres, 119, 2014.

Koch, D., Jacob, D., Tegen, I., Rind, D., and Chin, M.: Tropospheric sulfur simulation and sulfate direct radiative forcing in the Goddard Institute for Space Studies general circulation model, Journal of Geophysical Research-Atmospheres, 104, 23799-23822, 1999.

460 Kok, J. F.: A scaling theory for the size distribution of emitted dust aerosols suggests climate models underestimate the size of the global dust cycle, Proc. Natl. Acad. Sci. U. S. A., 108, 1016-1021, 2011.

Kok, J. F., Mahowald, N. M., Fratini, G., Gillies, J. A., Ishizuka, M., Leys, J. F., Mikami, M., Park, M. S., Park, S. U., Van Pelt, R. S., and Zobeck, T. M.: An improved dust emission model - Part 1: Model description and comparison against measurements, Atmos. Chem. Phys., 14, 13023-13041, 2014.

465 Kok, J. F., Ridley, D. A., Zhou, Q., Miller, R. L., Zhao, C., Heald, C. L., Ward, D. S., Albani, S., and Haustein, K.: Smaller desert dust cooling effect estimated from analysis of dust size and abundance, Nature Geoscience, 10, 274-278, 2017.

Krinner, G., Viovy, N., de Noblet-Ducoudre, N., Ogee, J., Polcher, J., Friedlingstein, P., Ciais, P., Sitch, S., and Prentice, I. C.: A dynamic global vegetation model for studies of the coupled atmospherebiosphere system, Global Biogeochemical Cycles, 19, 2005.

Marticorena, B. and Bergametti, G.: Modeling the atmospheric dust cycle .1. Design of a soil-derived emission scheme, Journal of Geophysical Research-Atmospheres, 100, 16415-16430, 1995.

Matthes, K., Funke, B., Andersson, M. E., Barnard, L., Beer, J., Charbonneau, P., Clilverd, M. A., de Wit, T. D., Haberreiter, M., Hendry, A., Jackman, C. H., Kretzschmar, M., Kruschke, T., Kunze, M., Langematz, U., Marsh, D. R., Maycock, A. C., Misios, S., Rodger, C. J., Scaife, A. A., Seppala, A., Shangguan, M., Sinnhuber, M., Tourpali, K., Usoskin, I., De Kamp, M. V., Verronen, P. T., and Versick, S.: Solar forcing for CMIP6 (v3.2), Geoscientific Model Development, 10, 2247-2302, 2017.

Miller, R. L., Cakmur, R. V., Perlwitz, J., Geogdzhayev, I. V., Ginoux, P., Koch, D., Kohfeld, K. E., Prigent, C., Ruedy, R., Schmidt, G. A., and Tegen, I.: Mineral dust aerosols in the NASA goddard institute for Space Sciences ModelE atmospheric general circulation model, J. Geophys. Res.-Atmos., 111, D06208, 2006.

Myriokefalitakis, S., Ito, A., Kanakidou, M., Nenes, A., Krol, M. C., Mahowald, N. M., Scanza, R. A., Hamilton, D. S., Johnson, M. S., Meskhidze, N., Kok, J. F., Guieu, C., Baker, A. R., Jickells, T. D., Sarin, M. M., Bikkina, S., Shelley, R., Bowie, A., Perron, M. M. G., and Duce, R. A.: Reviews and syntheses: the GESAMP atmospheric iron deposition model intercomparison study, Biogeosciences, 15, 6659-6684, 2018.

Perez, C., Haustein, K., Janjic, Z., Jorba, O., Huneeus, N., Baldasano, J. M., Black, T., Basart, S., Nickovic, S., Miller, R. L., Perlwitz, J. P., Schulz, M., and Thomson, M.: Atmospheric dust modeling from meso to global scales with the online NMMB/BSC-Dust model - Part 1: Model description, annual simulations and evaluation, Atmospheric Chemistry and Physics, 11, 13001-13027, 2011.

Perlwitz, J. P., Perez Garcia-Pando, C., and Miller, R. L.: Predicting the mineral composition of dust aerosols - Part 1: Representing key processes, Atmos. Chem. Phys., 15, 11593-11627, 2015.

Prospero, J. M., Ginoux, P., Torres, O., Nicholson, S. E., and Gill, T. E.: Environmental characterization of global sources of atmospheric soil dust identified with the Nimbus 7 Total Ozone Mapping Spectrometer (TOMS) absorbing aerosol product, Reviews of Geophysics, 40, 1002, 2002.

Randles, C. A., da Silva, A. M., Buchard, V., Colarco, P. R., Darmenov, A., Govindaraju, R., Smirnov, A., Holben, B., Ferrare, R., Hair, J., Shinozuka, Y., and Flynn, C. J.: The MERRA-2 Aerosol Reanalysis, 1980 Onward. Part I: System Description and Data Assimilation Evaluation, Journal of Climate, 30, 6823-6850, 2017.

500 Raupach, M. R., Gillette, D. A., and Leys, J. F.: The effect of roughness elements on wind erosion threshold, Journal of Geophysical Research-Atmospheres, 98, 3023-3029, 1993. 
Ridley, D. A., Heald, C. L., Kok, J. F., and Zhao, C.: An observationally-constrained estimate of global dust aerosol optical depth, Atmos. Chem. Phys., 16, 15097-15117, 2016.

Rienecker, M. M., Suarez, M. J., Todling, R., Bacmeister, J., Takacs, L., Liu, H.-C., Gu, W., Sienkiewicz, M., Koster, R. D., Gelaro, R., Stajner, I., and Nielsen, J. E.: The GEOS-5 Data Assimilation System Documentation of Versions 5.0.1, 5.1.0, and 5.2.0, 2008.

Ryder, C. L., Highwood, E. J., Rosenberg, P. D., Trembath, J., Brooke, J. K., Bart, M., Dean, A., Crosier, J., Dorsey, J., Brindley, H., Banks, J., Marsham, J. H., McQuaid, J. B., Sodemann, H., and Washington, R.: Optical properties of Saharan dust aerosol and contribution from the coarse mode as measured during the Fennec 2011 aircraft campaign, Atmospheric Chemistry and Physics, 13, 303325, 2013.

Scanza, R., Mahowald, N., Ghan, S., Zender, C. S., Kok, J. F., Liu, X., Zhang, Y., and Albani, S.: Modeling dust as component minerals in the Community Atmosphere Model: development of framework and impact on radiative forcing, Atmos. Chem. Phys., 15, 537-561, 2015.

Scanza, R. A., Hamilton, D. S., Pérez Garcia-Pando, C., Buck, C., Baker, A., and Mahowald, N. M.: Atmospheric processing of iron in mineral and combustion aerosols: development of an intermediatecomplexity mechanism suitable for Earth system models, Atmospheric Chemistry and Physics, 18, 14175-14196, 2018.

Schmidt, G. A., Ruedy, R., Hansen, J. E., Aleinov, I., Bell, N., Bauer, M., Bauer, S., Cairns, B., Canuto, V., Cheng, Y., Del Genio, A., Faluvegi, G., Friend, A. D., Hall, T. M., Hu, Y. Y., Kelley, M., Kiang, N. Y., Koch, D., Lacis, A. A., Lerner, J., Lo, K. K., Miller, R. L., Nazarenko, L., Oinas, V., Perlwitz, J., Rind, D., Romanou, A., Russell, G. L., Sato, M., Shindell, D. T., Stone, P. H., Sun, S., Tausnev, N., Thresher, D., and Yao, M. S.: Present-day atmospheric simulations using GISS ModelE: Comparison to in situ, satellite, and reanalysis data, Journal of Climate, 19, 153-192, 2006.

Schulz, M., Cozic, A., and Szopa, S.: LMDzT-INCA dust forecast model developments and associated validation efforts, IOP Conference Series: Earth and Environmental Science, 7, 2009.

Shao, Y.: A model for mineral dust emission, Journal of Geophysical Research-Atmospheres, 106, 20239-20254, 2001.

Shao, Y., Ishizuka, M., Mikami, M., and Leys, J. F.: Parameterization of size-resolved dust emission and validation with measurements, Journal of Geophysical Research-Atmospheres, 116, D08203, 2011.

Shao, Y. P.: Simplification of a dust emission scheme and comparison with data, Journal of Geophysical Research-Atmospheres, 109, D10202, 2004.

Shao, Y. P. and Lu, H.: A simple expression for wind erosion threshold friction velocity, Journal of Geophysical Research-Atmospheres, 105, 22437-22443, 2000.

Shao, Y. P., Raupach, M. R., and Findlater, P. A.: Effect of saltation bombardment on the entrainment of dust by wind, Journal of Geophysical Research-Atmospheres, 98, 12719-12726, 1993.

Shao, Y. P., Raupach, M. R., and Leys, J. F.: A model for predicting aeolian sand drift and dust entrainment on scales from paddock to region, Australian Journal of Soil Research, 34, 309-342, 1996.

540 Wang, M. and Penner, J. E.: Aerosol indirect forcing in a global model with particle nucleation, Atmospheric Chemistry and Physics, 9, 239-260, 2009.

Webb, N. P., Okin, G. S., and Brown, S.: The effect of roughness elements on wind erosion: The importance of surface shear stress distribution, Journal of Geophysical Research-Atmospheres, 119, 6066-6084, 2014.

545 Wesely, M. L. and Hicks, B. B.: Some factors that affect deposition rates of sulfur-dioxide and similar gases on vegetation, Journal of the Air Pollution Control Association, 27, 1110-1116, 1977.

Wu, C. C., Lin, Z., and Liu, X.: The global dust cycle and uncertainty in CMIP5 (Coupled Model Intercomparison Project phase 5) models, Atmospheric Chemistry and Physics, 20, 10401-10425, 2020.

550 Zender, C. S., Bian, H. S., and Newman, D.: Mineral Dust Entrainment and Deposition (DEAD) model: Description and 1990s dust climatology, Journal of Geophysical Research-Atmospheres, 108, 4416, 2003. 